\title{
Awareness, Access and Knowledge of Teachers and Students about Information and Communication Technologies (ICTs)
}

\author{
Naaz Bano* and Seema Rani \\ Department of extension education and communication management, CCS HAU, Hisar, India \\ *Corresponding author
}

\section{A B S T R A C T}

\section{Keywords}

ICT, Education, Learning, Teaching, Technology

\section{Article Info}

Accepted:

12 December 2020

Available Online:

10 January 2021
ICT stands for Information and Communication Technologies these technologies comprises computer, telephone, internet, television, radio etc. In $21^{\text {st }}$ century, use of ICTs becomes more prominent in all the sectors which include organizations, academics and education etc. ICTs have introduced new methods of teaching and conducting research. The integration of ICTs into educational classroom teaching has attained a new upsurge nowadays. It has the potential to boost information distribution, learning, teaching and educational services and makes them affordable and accessible anytime, anywhere. The present study on "Awareness, access and knowledge of teachers and students about information and communication technologies (ICTs)" was conducted in CCS HAU Hisar with a sample size of 100 teachers and 150 students. The data was collected on awareness, access and knowledge about selected ICT tools with the help of the questionnaire. Finding of the study showed that cent percent of the teachers and students were having awareness about Internet/ Web services, MS PowerPoint. Friends and relatives played major source of awareness $(71.60 \%)$ about ICT tools for most of the respondents. All the teachers $(100.00 \%)$ were having accessibility of official computer in the department, internet access in the university and internet access in the faculty/department followed by personal computer (desktop/laptop) (98.00\%) and CD-ROM access in the university library (87.00\%).Majority of the teachers (94.00\%) and students (88.67) were having high knowledge of ICT tools. Hence, ICT is an important source of information for teachers and students. Access to different forms of information and communication technologies had increased the ability of teachers and students to carry out more informed research.

\section{Introduction}

The beginning of the twenty-first century has seen a number of technological developments which affect every aspect of our lives. The ever-growing Information and Communication Technologies (ICTs) can be seen in all realms of life, from the workplace to the sports field, in schools and on a personal or social level.

ICT has become valuable source of modernization and improvement of proficiency for many sectors across the globe. In the education area, particularly, the use of ICT has become a critical part of the learning 
process for university students. Universities that have fully adopted ICT have noted immense advancement in the application of ICT for the up gradation of learning methods, teaching, research, and development. The fast speed of technological change in education has made it challenging for Faculty of Education professors to keep up-to-date with the integration of Information and Communication Technology (ICT) into teaching. The role of ICTs as an instrument for progress and development has been widely recognized in this 'Global Information age' and it has been witnessed that people with all walk of life are being influenced by the IT sector directly or indirectly.

Globalization and innovations in technology have led to an increased use of ICTs in education. Teachers use several ICTsinternet, video, audio, graphics, text, images, etc to offer students live experience of learning. Uses of ICTs in education are widespread and growing worldwide. Appropriate use of ICTs can renovate the whole teaching- learning processes leading to paradigm shift in teaching methodology (Sharma et al., 2011).

Keeping in mind the role of ICTs, the study was carried out with the following specific objectives include to study the awareness of ICT tools by the teachers and students. To study the access of ICT tools by the teachers and students. To study the knowledge and source of knowledge of ICT tools by the teachers and students

Thangaraja et al., (2008) conducted a study on the utilization pattern of online journals by the students of Tamil Nadu Agricultural University (TNAU). The results showed that majority $(95.00 \%)$ of the students were aware about the accessibility of online journals which are related to their respective subjects.

Isiaka and Abubakar (2008) reported that most of the extensionists largely used e-mail, online chat, e-publications, file transfer protocol and the world wide web, all of the which they desired to learn more about.

According to Mishra (2008) more research and development in the ICT will not only help in the development and information area but will also assist people to get skill, knowledge etc.

Reddy (2008) conducted a study to present a solution to bridge the information gap by exploiting advances in information technology (IT). A framework was planned of cost effective agriculture knowledge to the farming community to improve the crop with expertise.

Zakaria et al., (2010) conducted the research on use of web 2.0 technology by Malaysian students. The general opinion gathered about the integration of web 2.0 tools into learning was positive. Result indicated that students preferred using e mail to disseminate and share digital contents. Similarly it was also observed that for finding information related to education, students prefer to use search engines instead of asking colleagues or teachers.

Sharma and Hasan (2012) concluded that most of the respondents owned various communication media as mobile phone, internet, newspaper and magazine. Majority of respondents had knowledge about the various software uses in the computer like MS Word, MS power - point and MS excel etc.

Adebayo (2012) concluded that information and communication technology (ICT) have significant impact in the administration of polytechnic in Ogun, State Nigeria. The impact were found to be relevant to senior academic \& administration officers of polytechnics in ICT providing solutions to 
specific problems of administration, ICT enhance qualitative and quantitative. ICT encourages competency of administrators in decision-making in the administration of polytechnic. It also guarantees effective administrative practices of human and material resources; ICT has capacity to handle equality of data for processing with fastest speed. Nakweya (2013) found that traditional ICTs viz., radio and television have also been reported to be used by farmers in accessing agriculture related information.

Woreta et al., (2013) observed the knowledge and utilization of ICT among 1096 students. The result indicated that $33 \%$ of the students used a computer once a week and almost $41 \%$ once in a month. Nearly half of the students (47\%) never used ICTs. In addition, the result showed that the majority of the students $(51 \%)$ use ICTs for email or instant messaging only.

Verma and Dahiya (2015) reported no significant difference between student and faculty towards ICT knowledge. Male faculties were more conscious about ICTs as compared to boys' student. Female faculty won from girl's student in understanding of ICT knowledge.

James and Lakshminarayan (2018) found that three-fourth $(75.00 \%)$ of the agriculture extension functionaries were having high and medium level of overall knowledge about ICT tools. A variation of 72.80 per cent was observed in the knowledge of agriculture extension functionaries about ICT tool.

\section{Materials and Methods}

\section{Selection of the population}

The study was conducted in the purposively selected Chaudhary Charan Singh Haryana Agricultural University, Hisar, Haryana. All the colleges of university including I.C. College of Home Science, College of Basic Sciences, College of Agriculture and College of Agriculture Engineering \& Technologies were selected for conducting research on the usage of ICTs by teachers and students.

\section{Selection of students}

The proportionate sample of 150 post graduate doing M.Sc, M.Tech, MBA and P.hd students was selected from all the colleges of CCS HAU, Hisar, Haryana. Simple random sampling technique was used for selection of the respondents.

\section{Selection of the Teachers}

The sample of 100 teachers was selected from all the colleges of Chaudhary Charan Singh Haryana Agricultural University, Hisar, Haryana. Simple random sampling technique was used for selection of the respondents. The teachers for the study were operationalized as a teacher engaged in teaching courses.

Selection of ICT tools- In this study a total of seven ICT tools were selected after relevant review of literature, getting suggestions and guidance of the experts. The ICT tools selected were

Internet/Web services

MS Word

MS Excel

MS Power Point

Mobile Technology

Digital transaction

Interactive Multimedia Compact Disc

\section{Instruments for data collection}

Keeping in view the objectives and the variables under study, questionnaire was prepared for both students and teachers separately and pre-tested on a non-sampled 
respondents to find any ambiguity in the questions.

After pre-testing some modifications were made in the questionnaire by consulting experts and finalized questionnaire was used for data collection. The questionnaire contains both close and open ended types of questions.

\section{Awareness}

Awareness model has two fold natures, that is they include a representation of one's existing state or behaviour matched to some standards.

This indicates that awareness consists of both an object of attention and an evaluate context in which that object is framed. Awareness about ICT tools was categorized as Yes/No

Awareness regarding the selected ICT tools- Here the awareness regarding the selected ICT tools was classified into following categories.

\begin{tabular}{|l|c|}
\hline Category & Score \\
\hline Yes & 2 \\
\hline No & 1 \\
\hline
\end{tabular}

Sources of Awareness - The sources of awareness were classified under four categories.

\begin{tabular}{|l|c|}
\hline Category & Scores \\
\hline Radio & $\mathbf{1}$ \\
\hline T.V. & $\mathbf{2}$ \\
\hline Print Media & $\mathbf{3}$ \\
\hline Friends/ Relatives & $\mathbf{4}$ \\
\hline By the online course & $\mathbf{5}$ \\
\hline
\end{tabular}

Awareness about the facilities, available in the university library system

\begin{tabular}{|l|c|c|}
\hline Facilities & Yes & No \\
\hline Internet technology & 2 & 1 \\
\hline WIFI & 2 & 1 \\
\hline
\end{tabular}

\begin{tabular}{|c|c|c|}
\hline Digital library resources & 2 & 1 \\
\hline Desktop & 2 & 1 \\
\hline $\begin{array}{ll}\text { Radio } & \text { frequency } \\
\text { technology } & \end{array}$ & 2 & 1 \\
\hline $\begin{array}{l}\text { Online public access } \\
\text { catalogue }\end{array}$ & 2 & 1 \\
\hline E-mail facilities & 2 & 1 \\
\hline CD-ROM technology & 2 & 1 \\
\hline
\end{tabular}

Accessibility of ICT facilities by the teachers and students in the department

\begin{tabular}{|l|c|c|}
\hline Facilities & Yes & No \\
\hline $\begin{array}{l}\text { Official computer in the } \\
\text { department }\end{array}$ & 2 & 1 \\
\hline $\begin{array}{l}\text { Personal computer } \\
\text { (desktop/laptop) }\end{array}$ & 2 & 1 \\
\hline $\begin{array}{l}\text { Internet access in university } \\
\text { library }\end{array}$ & 2 & 1 \\
\hline $\begin{array}{l}\text { Internet access in } \\
\text { faculty/department }\end{array}$ & 2 & 1 \\
\hline $\begin{array}{l}\text { CD-ROM access in } \\
\text { university }\end{array}$ & 2 & 1 \\
\hline
\end{tabular}

\section{Knowledge}

Bloom et al., (1969) defined knowledge as those behaviours and test conditions, which highlight the remembering either by recognition or by recall of ideas and materials on the same phenomenon.

\section{Knowledge regarding ICT tools}

Statements based on certain significant aspects of Information and Communication Technology Tools were framed and pre-tested on a non sampled respondents. Finally on the basis of the experience gained in pre testing, 35 statements were selected regarding 7 ICT tools. They were presented to the respondents with 5 possible answers for each tool and selecting the correct answer. A score of two was given to the right answer and one to the wrong answer. The possible obtainable scores 
ranged between 70 and 35 respectively. Based on the total scores, the respondents were categorized into three categories namely low, medium and high.

Further, the total knowledge score of respondents for all the statements were calculated by summing up the number of statements answered and respondents were grouped into three categories following the equal distribution method based on class interval as follows:

Procedure for categorization was followed by Manjula (2000).

Maximum score - Minimum score $=$ Class interval 70-35 $=11.66$ i.e. 12.00

\begin{tabular}{|l|c|}
\hline Category & Range \\
\hline Low & $35-46$ \\
\hline Medium & $47-58$ \\
\hline High & $59-70$ \\
\hline
\end{tabular}

Sources of Knowledge- The sources of knowledge regarding ICT tools were categorized into following types.

\begin{tabular}{|l|c|}
\hline Category & Score \\
\hline Self & $\mathbf{1}$ \\
\hline Home & $\mathbf{2}$ \\
\hline Office & $\mathbf{3}$ \\
\hline Through teaching & $\mathbf{4}$ \\
\hline Through training & $\mathbf{5}$ \\
\hline $\begin{array}{l}\text { Through Summer/ } \\
\text { Winter Camp }\end{array}$ & $\mathbf{6}$ \\
\hline $\begin{array}{l}\text { Cyber Café } \\
\text { Through friends/ } \\
\text { Colleagues }\end{array}$ & $\mathbf{7}$ \\
\hline
\end{tabular}

\section{Results and Discussion}

\section{Awareness of selected tools}

It is clear from the Table-3 and Fig. 4.1that cent per cent of the teacher were aware about the Internet/ Web services, MS Word, MS Excel, MS PowerPoint and Mobile Technology. While, more number of the teacher were aware about Digital transaction (online payment) $(98.00 \%)$ followed by Interactive Multimedia Compact Disc (IMCD) 90.00 per cent.

With respect to the students all of them $(100.00 \%)$ had awareness about Internet/ Web services, MS PowerPoint and Mobile Technology. While, majority of the students were aware about MS Word (99.33\%), MS Excel (98.67\%), Digital Transaction (96.66\%) and Interactive Multimedia Compact Disc (IMCD) 87.33 per cent.

\section{Source of awareness of ICT tools}

The data of Table- 4 and Fig. 4.2 depicts the source of awareness of ICT tools by teachers and students. Majority of the teachers were getting information of ICT tools from friends or relatives $(71.00 \%)$ followed by print media (63.00\%), TV $(42.00 \%)$, radio $(28.00 \%)$, through the training $(9.00 \%)$ and by the online course $(6.00 \%)$. In case of students, highest source of information was also friends or relatives $(71.33 \%)$ followed by print media (28.00\%), TV $(27.33 \%)$, radio $(10.66 \%)$, through the training $(3.33 \%)$ and by the online courses $(1.33 \%)$.

Awareness about the facilities, available in the university library system by the teachers and students

The results from Table- 5 shows that all of the teachers $(100.00 \%)$ were aware of internet facility available in the university library system followed by E-mail facility $(96.00 \%)$, desktop (95.00\%), WIFI (94.00\%), digital library resources $(92.00 \%)$, online public access catalogue $(78.00 \%)$, CD ROM $(85.00 \%)$ and radio frequency technology $(34.00 \%)$. 
With regard to the students majority of the students (96.00\%) were aware about desktop facility available in the university library system followed by internet facility and WIFI $(92.00 \%)$, digital library resources $(87.33 \%)$, online public access catalogue $(79.33 \%)$, Email facility (76.66\%) and CD ROM $(66.66 \%)$.

Accessibility of ICT facilities by the teachers and students in the department

It becomes clearly evident from Table-6, that cent per cent $(100.00 \%)$ teachers were having accessibility of official computer in the department, internet access in the university and internet access in the faculty/department followed by personal computer (desktop/laptop) (98.00\%) and CD-ROM access in the university library $(87.00 \%)$.

With respect to the students majority of the students having accessibility of internet access in the university $(96.00 \%)$ followed by the official computer in the department (94.00\%), internet access to faculty/department (93.00\%), personal computer and CD-ROM access in the university library $(89.33 \%)$.

Table.1 Awareness of selected ICT tools by teachers and students

\begin{tabular}{|c|c|c|c|c|}
\hline $\begin{array}{l}\text { Sr. } \\
\text { No }\end{array}$ & ICT tools & $\begin{array}{c}\text { Teachers } \\
(\mathbf{n}=100) \\
\text { F }(\%)\end{array}$ & $\begin{array}{c}\text { Students } \\
(\mathbf{n}=150) \\
\text { F }(\%)\end{array}$ & $\begin{array}{c}\text { Total ' } \mathbf{N} \text { ' } \\
(250) \\
\text { F (\%) }\end{array}$ \\
\hline 1. & Internet/ Web services & $100(100.00)$ & $150(100.00)$ & $250(100.00)$ \\
\hline 2. & MS Word & $100(100.00)$ & 149(99.33) & $249(99.60)$ \\
\hline 3. & MS Excel & $100(100.00)$ & $148(98.67)$ & 248(99.20) \\
\hline 4. & MS PowerPoint & $100(100.00)$ & $150(100.00)$ & $250(1000.00)$ \\
\hline 5. & Mobile Technology & $100(100.00)$ & $150(100.00)$ & $250(1000.00)$ \\
\hline 6. & Digital transaction & 98(98.00) & $145(96.66)$ & 243(97.20) \\
\hline 7. & $\begin{array}{l}\text { Interactive Multimedia Compact Disc } \\
\text { (IMCD) }\end{array}$ & $90(90.00)$ & $131(87.33)$ & $221(88.40)$ \\
\hline
\end{tabular}

Table.2 Source of awareness of ICT tools by the teachers and students

\begin{tabular}{|c|l|c|c|c|}
\hline $\begin{array}{l}\text { Sr. } \\
\text { No }\end{array}$ & Source & $\begin{array}{c}\text { Teachers } \\
(\mathbf{n = 1 0 0}) \\
\mathbf{F}(\mathbf{\%})\end{array}$ & $\begin{array}{c}\text { Students } \\
(\mathbf{n = 1 5 0 )} \\
\mathbf{F}(\boldsymbol{\%})\end{array}$ & $\begin{array}{c}\text { Total 'N' (250) } \\
\text { F (\%) }\end{array}$ \\
\hline 1. & Radio & $28(28.00)$ & $16(10.66)$ & $44(17.60)$ \\
\hline 2. & TV & $42(42.00)$ & $41(27.33)$ & $83(33.20)$ \\
\hline 3. & Print media & $63(63.00)$ & $42(28.00)$ & $105(42.00)$ \\
\hline 4. & Friends/ Relatives & $71(71.00)$ & $107(71.33)$ & $179(71.60)$ \\
\hline 5. & By the online courses & $6(6.00)$ & $2(1.33)$ & $8(3.20)$ \\
\hline
\end{tabular}

Note: 1. Multiple responses are possible 
Table.3 Awareness about the ICT facilities, available in the university library system to the teachers and students

\begin{tabular}{|c|l|c|c|c|}
\hline $\begin{array}{l}\text { Sr. } \\
\text { No }\end{array}$ & ICT tools & $\begin{array}{c}\text { Teachers } \\
(\mathbf{n = 1 0 0}) \\
\mathbf{F}(\boldsymbol{\%})\end{array}$ & $\begin{array}{c}\text { Students } \\
(\mathbf{n = 1 5 0}) \\
\mathbf{F}(\boldsymbol{\%})\end{array}$ & $\begin{array}{c}\text { Total 'N' } \\
\mathbf{F}(\mathbf{\%})\end{array}$ \\
\hline $\mathbf{1 .}$ & Internet technology & $100(100.00)$ & $138(92.00)$ & $238(95.20)$ \\
\hline $\mathbf{2 .}$ & WIFI & $94(94.00)$ & $138((92.00)$ & $232(92.80)$ \\
\hline 3. & Digital library resources & $92(92.00)$ & $131(87.33)$ & $223(89.20)$ \\
\hline $\mathbf{4 .}$ & Desktop & $95(95.00)$ & $145(96.00)$ & $240(96.00)$ \\
\hline $\mathbf{5 .}$ & Radio Frequency technology & $34(34.00)$ & $70(46.66)$ & $104(41.60)$ \\
\hline $\mathbf{6 .}$ & $\begin{array}{l}\text { Online Public Access } \\
\text { Catalogue }\end{array}$ & $78(78.00)$ & $119(79.33)$ & $197(78.80)$ \\
\hline 7. & E-mail facilities & $96(96.00)$ & $115(76.66)$ & $211(84.40)$ \\
\hline 8. & CD-ROM technology & $85(85.00)$ & $100(66.66)$ & $176(70.40)$ \\
\hline
\end{tabular}

Table.4 Accessibility of ICT facilities to the teachers and students in the department

\begin{tabular}{|c|c|c|c|c|}
\hline $\begin{array}{l}\text { Sr. } \\
\text { No. }\end{array}$ & Infrastructure & $\begin{array}{c}\text { Teachers } \\
(\mathbf{n}=100) \\
\text { F }(\%)\end{array}$ & $\begin{array}{c}\begin{array}{c}\text { Students } \\
(\mathrm{n}=150)\end{array} \\
\mathbf{F}(\%)\end{array}$ & $\begin{array}{l}\text { Total 'N' (250) } \\
\text { F (\%) }\end{array}$ \\
\hline 1. & $\begin{array}{l}\text { Official computer in the } \\
\text { department }\end{array}$ & $100(100.00)$ & $141(94.00)$ & 241(96.40) \\
\hline 2. & $\begin{array}{ll}\begin{array}{l}\text { Personal } \\
\text { (desktop/laptop) }\end{array} & \text { computer }\end{array}$ & 98(98.00) & 134(89.33) & 232(92.80) \\
\hline 3. & Internet access in university & $100(100.00)$ & 144(96.00) & 244(97.60) \\
\hline 4. & $\begin{array}{l}\text { Internet access in the } \\
\text { faculty/department }\end{array}$ & $100(100.00)$ & $140(93.33)$ & $240(96.00)$ \\
\hline 5. & $\begin{array}{l}\text { CD-ROM access in university } \\
\text { library }\end{array}$ & $87(87.00)$ & $134(89.33)$ & $221(88.40)$ \\
\hline
\end{tabular}

Table.5 Knowledge of ICT tools by teachers and students

\begin{tabular}{|r|l|c|c|c|}
\hline $\begin{array}{r}\text { Sr. } \\
\text { No. }\end{array}$ & Knowledge categories (Score) & $\begin{array}{c}\text { Teachers (n=100) } \\
\text { F (\%) }\end{array}$ & $\begin{array}{c}\text { Students }(\mathbf{n = 1 5 0}) \\
\text { F (\%) }\end{array}$ & $\begin{array}{c}\text { Total(N=250) } \\
\text { F (\%) }\end{array}$ \\
\hline 1. & Low(35-46) & - & $1(0.67)$ & $1(0.40)$ \\
\hline 2. & Medium(47-58) & $6(6.00)$ & $16(10.66)$ & $22(8.80)$ \\
\hline 3. & High(59-70) & $94(94.00)$ & $133(88.67)$ & $227(90.80)$ \\
\hline
\end{tabular}


Table.6 Source of knowledge of teachers regarding ICT tools N=100

\begin{tabular}{|c|c|c|c|c|c|c|c|c|c|}
\hline \multirow{2}{*}{$\begin{array}{l}\text { Sr. } \\
\text { No. }\end{array}$} & \multirow[t]{2}{*}{ ICT Tools } & \multicolumn{8}{|c|}{ Source of knowledge } \\
\hline & & $\begin{array}{l}\text { Self } \\
(\%)\end{array}$ & $\begin{array}{l}\text { Home } \\
(\%)\end{array}$ & $\begin{array}{c}\text { Office/ } \\
\text { Institutio } \\
\mathbf{n} \\
(\%)\end{array}$ & $\begin{array}{c}\text { Through } \\
\text { teaching } \\
(\%)\end{array}$ & $\begin{array}{c}\text { Through } \\
\text { training } \\
(\%)\end{array}$ & $\begin{array}{c}\text { Through } \\
\text { Summer/Wint } \\
\text { er Camp }(\%)\end{array}$ & $\begin{array}{c}\text { Cyber } \\
\text { café } \\
(\%)\end{array}$ & $\begin{array}{c}\text { Through } \\
\text { Friends/ } \\
\text { Colleagues }(\%)\end{array}$ \\
\hline 1. & $\begin{array}{l}\text { Internet/web } \\
\text { services }\end{array}$ & $47(47.00)$ & $4(4.00)$ & $11(11.00)$ & $5(5.00)$ & $18(18.00)$ & - & $2(2.00)$ & $16(16.00)$ \\
\hline 2. & MS Word & $37(37.00)$ & $16(16.00)$ & $19(19.00)$ & $9(9.00)$ & $21(21.00)$ & $1(1.00)$ & $5(5.00)$ & $16(16.00)$ \\
\hline 3. & MS Excel & $36(36.00)$ & $14(14.00)$ & $22(22.00)$ & $10(10.00)$ & $25(25.00)$ & - & $4(4.00)$ & $15(15.00)$ \\
\hline 4. & MS PowerPoint & $37(37.00)$ & $11(11.00)$ & $34(34.00)$ & $9(9.00)$ & $24(24.00)$ & $1(1.00)$ & $6(6.00)$ & $17(17.00)$ \\
\hline 5. & $\begin{array}{l}\text { Mobile } \\
\text { Technology }\end{array}$ & $48(48.00)$ & $9(9.00)$ & 19(19.00) & $7(7.00)$ & $18(18.00)$ & $3(3.00)$ & $8(8.00)$ & 21(17.00) \\
\hline 6. & $\begin{array}{l}\text { Digital } \\
\text { transaction }\end{array}$ & $45(45.00)$ & $6(6.00)$ & $21(21.00)$ & $9(9.00)$ & $19(19.00)$ & - & $11(11.00)$ & $25(25.00)$ \\
\hline 7. & $\begin{array}{l}\text { Interactive } \\
\text { Multimedia } \\
\text { Compact Disc } \\
\text { (IMCD) }\end{array}$ & 32(32.00) & $14(14.00)$ & $20(20.00)$ & 13(13.00) & $18(18.00)$ & - & - & $29(29.00)$ \\
\hline
\end{tabular}

Note: 1.Multiple responses are possible

Table.7 Source of knowledge of students regarding ICT tools N=150

\begin{tabular}{|c|c|c|c|c|c|c|c|c|c|}
\hline \multirow{2}{*}{$\begin{array}{l}\text { Sr. } \\
\text { No. }\end{array}$} & \multirow[t]{2}{*}{ ICT Tools } & \multicolumn{8}{|c|}{ Source of knowledge } \\
\hline & & $\begin{array}{c}\text { Self } \\
\text { F }(\%)\end{array}$ & $\begin{array}{l}\text { Home } \\
\text { F }(\%)\end{array}$ & $\begin{array}{c}\text { Office/ } \\
\text { Institution } \\
\text { F }(\%)\end{array}$ & $\begin{array}{c}\text { Through } \\
\text { teaching } \\
\text { F }(\%)\end{array}$ & $\begin{array}{c}\text { Through } \\
\text { training } \\
\text { F }(\%)\end{array}$ & $\begin{array}{c}\text { Through } \\
\text { Summer/ } \\
\text { Winter } \\
\text { Camp F }(\%)\end{array}$ & $\begin{array}{l}\text { Cyber } \\
\text { café } \\
\text { F }(\%)\end{array}$ & $\begin{array}{l}\text { Through } \\
\text { Friends/ } \\
\text { Colleagues } \\
\text { F }(\%)\end{array}$ \\
\hline 1. & Internet/web services & $88(58.67)$ & $26(17.33)$ & $10(6.67)$ & $12(8.00)$ & $7(4.67)$ & - & - & 27(18.00) \\
\hline 2. & MS Word & $45(30.00)$ & $25(16.67)$ & $27(18.00)$ & $25(16.67)$ & $11(7.33)$ & - & - & $30(20.00)$ \\
\hline 3. & MS Excel & $40(26.67)$ & $28(18.67)$ & $35(23.33)$ & $24(16.00)$ & $14(9.33)$ & - & $7(4.67)$ & 27(18.00) \\
\hline 4. & MS PowerPoint & $47(31.33)$ & $22(14.67)$ & $29(19.33)$ & $25(16.67)$ & $13(8.67)$ & - & - & $28(18.67)$ \\
\hline 5. & Mobile Technology & $88(58.67)$ & $35(23.33)$ & $9(6.00)$ & $8(5.33)$ & $5(3.33)$ & - & - & $36(24.00)$ \\
\hline 6. & Digital transaction & $79(52.66)$ & $44(29.33)$ & $8(5.33)$ & $6(4.00)$ & $6(4.00)$ & - & $6(4.00)$ & $43(28.67)$ \\
\hline 7. & $\begin{array}{l}\text { Interactive } \\
\text { Multimedia Compact } \\
\text { Disc (IMCD) }\end{array}$ & $40(26.67)$ & $20(13.33)$ & 19(12.67) & $10(6.67)$ & 11(7.33) & $7(4.67)$ & $5(3.33)$ & $50(33.33)$ \\
\hline
\end{tabular}

Note: 1.Multiple responses are possible 
Fig.1 Awareness of the selected ICT tools by teachers and students

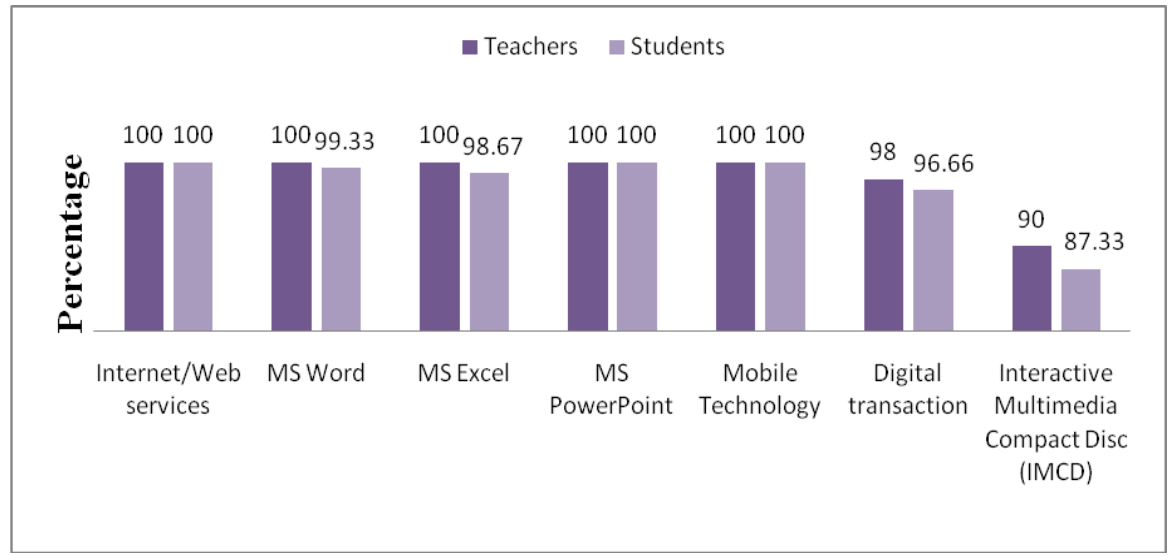

Fig.2 Source of awareness regarding ICT tools by the teachers and students

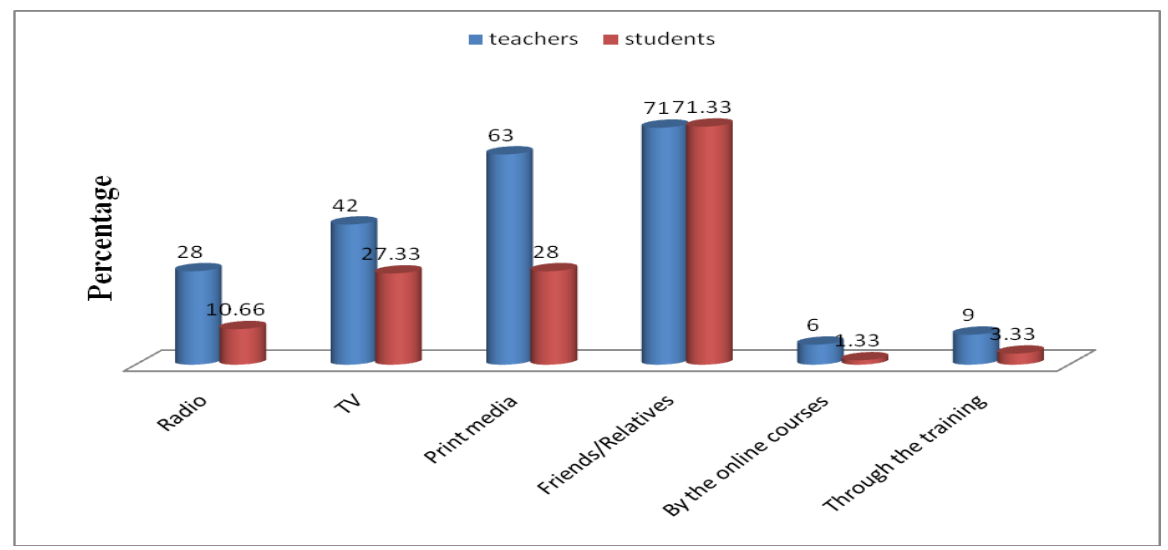

Fig.3 Knowledge level of teachers and students regarding ICT tools

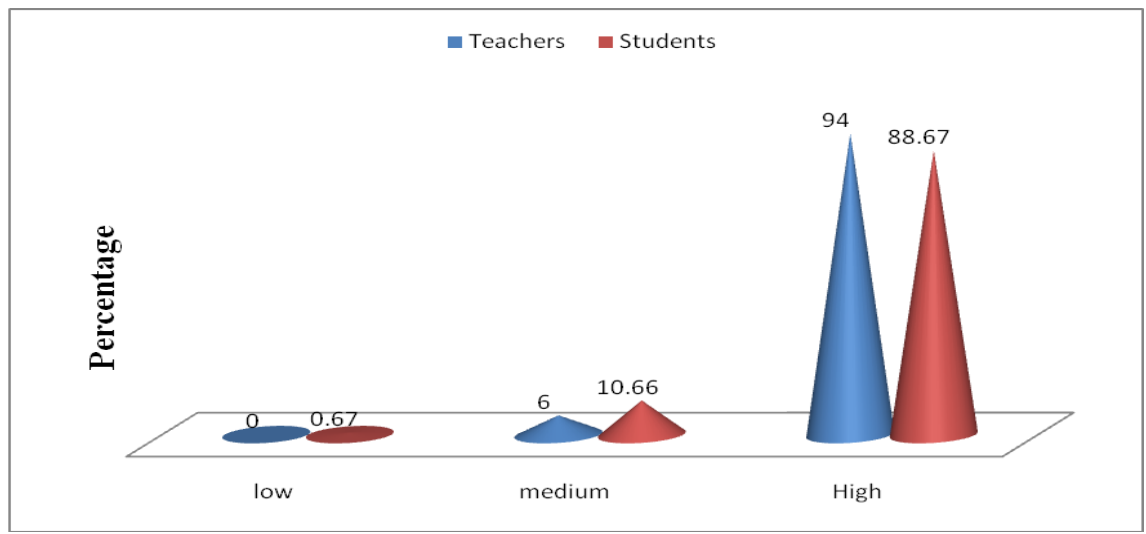


Knowledge of ICT tools by teachers and students

The critical evaluation of results (Table-7) and Fig. 4.3 predicts that majority of the teachers and students (94.00\%) and (88.67) were having high knowledge of ICT tools. Only few teachers (6.00) and students (10.66) were in the category of medium level knowledge $(6.00 \%)$ and $(10.66 \%)$ respectively. Only one student was found to have low knowledge of selected ICT tools.

\section{Source of Knowledge regarding ICT tools}

This part highlights the source of knowledge of teachers (Table-8 and 9) and students regarding seven selected ICT tools like Internet or Web services, MS Word, MS Excel etc. Eight sources like self, home, office, through teaching, through training, through summer or winter camp, cyber cafe and friends or colleagues were taken for the study.

Table- 8 depicts that more number of teachers were getting knowledge regarding internet by their own efforts $((47.00 \%)$ followed by through training $(18.00 \%)$, by the friends or colleagues (16.00\%), office institution $(11.00 \%)$, teaching $(5.00 \%)$ and through home $(4.00 \%)$. They procure more knowledge regarding MS Word also through self $(37.00 \%)$ followed by through training $(21.00 \%)$, office $(19.00 \%)$, friends or colleagues and home $(16.00 \%)$. With respect to the Digital transaction and Interactive Multimedia Compact Disc (IMCD) they were getting more knowledge by the self 45 per cent and 32 per cent respectively.

With respect to source of knowledge of ICT tools by students (Table-9), it was found that majority of them got knowledge regarding internet by their own efforts (58.67\%) followed by through friends or colleagues
(18.00\%), home (17.33\%), through teaching $(8.00 \%)$, office $(6.67 \%)$ and through training $(4.67 \%)$. They procure more knowledge about MS Word by the self $(45.00 \%)$ followed by through friends or colleagues $(20.00 \%)$ and office $(18.00 \%)$. They got more knowledge about MS Excel by their own efforts (26.67\%) followed by institution (23.33\%). In case of Digital transaction and Interactive Multimedia Compact Disc (IMCD) they were getting more knowledge by their own efforts 52.66 per cent and 26.67 per cent respectively.

With respect to source of knowledge about all the ICT tools by teachers and students, it may be concluded that most of them got knowledge by their own efforts.

Thus it is concluded that majority of the respondents had significant amount of awareness access and knowledge of information and communication technologies to enhance ICT competencies related to different aspects of their utilization. Hence, it can be said that ICT is a gateway to vast sources of information for teachers and students. This includes the case for ICT as having the great potential to increase access to knowledge. Access to different forms of information and communication technologies has increased the ability of teachers and students to carry out more informed research.. ICT in educational sector can greatly enhance the quality of education.

\section{References}

Adebayo, S. S. 2012, The Impact of Application of Information and Communication Technology (ICT) in the Administration of Polytechnics in Ogun State, Nigeria. Project report, National Open University of Nigeria, The school of Education.

Ansari, M.A and Pandey, N. 2013, Assessing the potential and use of mobile phones in 
agriculture. Karnataka Journal of Agricultural Sciences, 26(3): 388-392.

James Dishant Jajit and Lakshminarayan M.T. 2018, Knowledge of Agriculture Extension Functionaries Regarding Information and Communication Technology Tools, Asian Journal of Agricultural Extension, Economics \& Sociology., Vol. 24(3), PP. No. 1-7.

Isiaka, A. A. and Abubakar, L. F., 2008, The use of Cyber-cafes in Ilorin, Nigeria. The Electronic Library., 26(2):238 - 248.

Manjula, N., 2000, A study on job perception, job performance and job satisfaction of AAO (FW) in Karnataka, Ph.D. Thesis, Univ. Agric. Sci., Bangalore,Karnataka (India).

Mishra, R., 2008, evolutionary and revolutionary: information and communication technology .university news, 46(1) : 17-20.

Nakweya 2013 Radio, mobile phones could boost African farm yields.htt://www.scidev.net/subsaharanafrica/icts/news/radio-mobilphones-could-boost-african-farmyields.html.

Reddy PK. 2008. A Framework of information technology based agriculture information dissemination system to improve crop productivity, in: extension technologies from labs to farm Ed. Anadaraja, N..Chandrakandan, $\quad$ K. and ramasubramaniam, M. New India publishing agency ,pp353.

Sharma A and Hasan S. 2012.Information and communication technologies usage by undergraduate students in Pantnagar University. Journals of Communication of Studies 30(1): 132-138.

Sharma Anu, Gandhar Kapil and Seema, 2011, Role of ICT in the Process of Teaching and Learning. Journal of Education and Practice, Vol.,2, No 5, pp. 1-6

Thangaraja, K., Karthikeyan, C., Asokhan, M. and Rajasekaran, R., 2008, Study on the Utilization Behaviour of Online Journals by the Students of TNAU. The Madras Agric. J., 95(1-6):114-119.

Verma,C.and Dahiya S.(2015). A Competence Approach to ICT Knowledge in Relation to Occupation: A Study of Indian Universities. Global Journal of Computer Science and Technology: H Information \& Technology Volume 15 Issue 6 Version 1.0 Year 2015 Type: Double Blind Peer Reviewed International Research Journal Publisher: Global Journals Inc. (USA) Online ISSN: 09754172 \& Print ISSN: 0975-4350

Woreta, S. A., Kebede, Y., \&Zegeye, D. T. (2013).Konwledge and utilization of information communication technology (ICT) among health science students at the University of Gondar, North Western Ethiopia. BMC Medical Informatics and Decision Making, 13 (31), 2-7.

Zakaria MH, WatsonJ and Edwards SL. 2010.investigating the use of web 2.0 technology by malesyian students. Multicultural education \& technology Journal 4(1): 17-19. Zakaria, M. H., Watson, J. \& Edwards, S. L. (2010).Investigating the use of Web 2.0 technology by Malaysian students. Multicultural Education \& Technology Journal ,4(1): 17-29.

\section{How to cite this article:}

Naaz Bano and Seema Rani. 2021. Awareness, Access and Knowledge of Teachers and Students about Information and Communication Technologies (ICTs). Int.J.Curr.Microbiol.App.Sci. 10(01): 2049-2059. doi: https://doi.org/10.20546/ijcmas.2021.1001.236 